\title{
Rzeczywista liczba dzieci i młodzieży przebywających w instytucjonalnych formach opieki całkowitej w Polsce a wyzwania procesu deinstytucjonalizacji
}

Magdalena Błaszczyk*

\section{Streszczenie}

Celem artykułu jest zaspokojenie zapotrzebowania na dane dotyczące liczby dzieci i młodzieży przebywających w instytucjonalnych formach opieki całkowitej w Polsce. Dane te są konieczne do ustalenia skali niezbędnych do podjęcia działań, aby możliwe stało się przejście od opieki instytucjonalnej do opieki rodzinnej, świadczonej w środowisku lokalnym. Głównym problemem związanym z analizowaniem uwarunkowań deinstytucjonalizacji w zakresie wspierania dzieci i młodzieży oraz z planowaniem tego procesu jest całkowite pomijanie - zarówno w profesjonalnym dyskursie, jak i w statystykach - osób przebywających w instytucjach długoterminowej opieki całkowitej nienależących do systemu pieczy zastępczej. W artykule przedstawiono konsekwencje takiego podejścia oraz zaprezentowano wyniki oszacowania liczby osób w wieku 0-24 lat przebywających w instytucjach świadczących długoterminową opiekę w systemach pomocy społecznej, edukacji i zdrowia. Z przeprowadzonych badań wynika, że skala instytucjonalizacji dzieci i młodzieży w Polsce jest znacznie niedoszacowana, gdyż w 2019 r. w zależności od przyjętych kryteriów kwalifikacji instytucji, co do typu świadczonej opieki, znajdujące się w nich dzieci i młodzież stanowiły 20-35\% wszystkich osób umieszczonych poza rodzinami pochodzenia. Dolną granicę tego oszacowania wyznacza udział dzieci i młodzieży umieszczonych w placówkach systemu pieczy zastępczej (blisko

* Magdalena Błaszczyk - mgr, Uniwersytet Łódzki, Wydział Ekonomiczno-Socjologiczny, Instytut Gospodarki Przestrzennej, Katedra Ekonometrii Przestrzennej, magdalena.blaszczyk@edu.uni. lodz.pl 
17 tys. osób), a górną - suma wszystkich osób w wieku 0-24 lat przebywających w instytucjach opieki całkowitej, w tym m.in. w domach pomocy społecznej czy instytucjach opiekuńczo-leczniczych (niemal 30 tys.).

Słowa kluczowe: deinstytucjonalizacja, piecza zastępcza, instytucje opieki całkowitej, instytucjonalna piecza zastępcza, polityka społeczna, ekonomia społeczna

JEL: I38, J13

\section{Wstęp}

Z prowadzonych w ostatnich dziesięcioleciach badań naukowych wynika, że dzieci przebywające, choćby czasowo, w instytucjach opieki całkowitej doświadczają wielu negatywnych konsekwencji rozwojowych (Tizard, Rees 1974; Hodges, Tizard 1989; Brown 2009; Golczyńska-Grondas 2015). Należą do nich zarówno zmiany w zakresie rozwoju fizycznego, jak i konsekwencje psychologiczne (Jackson i in. 2010; Schmid i in. 2008; Bos i in. 2011; Szmajda, Gmitrowicz 2018). Negatywne zmiany obserwowane są również w obszarze powstawania więzi emocjonalnych, w rozwoju intelektualnym i językowym oraz rozwoju mózgu (Ogólnoeuropejskie wytyczne... 2012, s. 53-55). Dzieci wychowywane w instytucjach opieki całkowitej osiągają gorsze wyniki niemal na wszystkich polach edukacji i rozwoju w porównaniu z ich rówieśnikami pozostającymi pod opieką rodzin. Znacznie bardziej efektywne są rodzinne formy opieki (rodziny zastępcze, adopcje) niż instytucjonalne, gdyż umożliwiają one osiąganie rezultatów rozwojowych zbliżonych do uzyskiwanych w rodzinie pochodzenia (Boss i in. 2011; Rutter, O'Connor 2004). Co więcej, przeprowadzone przez Ruttera i O'Connora (2004) w Rumunii i Wielkiej Brytanii badania nad dziećmi adoptowanymi wykazały, że podopieczni instytucji przeniesieni w środowisko rodzinne dość szybko nadrabiali opóźnienia rozwojowe i tworzyli prawidłowe związki uczuciowe z członkami rodziny. Należy jednak zauważyć, że w przypadku najmłodszych dzieci nawet stosunkowo krótki pobyt w instytucji opieki całkowitej może negatywnie wpłynąć na rozwój mózgu i mieć nieodwracalne konsekwencje dla dobrobytu emocjonalnego i zachowania dziecka (Ogólnoeuropejskie wytyczne... 2012, za: Nelson, Koga 2004).

Odejście od instytucjonalnych form opieki zwiększa więc szanse na lepszy rozwój fizyczny i behawioralny dzieci pozbawionych opieki rodziny pochodzenia, a także przyczynia się do polepszenia ich osiągnięć edukacyjnych oraz sprzyja szybszej adaptacji do samodzielnego życia poza rodziną czy instytucją. Potwierdzają to m.in. raporty Najwyższej Izby Kontroli dotyczące funkcjonowania placówek opiekuńczo-wychowawczych (NIK 2012) oraz procesu usamodzielniania 
wychowanków (NIK 2014), zgodnie z którymi tylko nieliczni wychowankowie polskich instytucji opiekuńczo-wychowawczych kontynuują naukę na studiach wyższych $(10 \%)$, podczas gdy w niektórych przypadkach (powiatach) aż 50\% podopiecznych rodzinnych form pieczy ${ }^{1}$ zastępczej podjęło studia. Ponadto wychowankowie instytucji znacznie częściej niż dzieci z rodzin zastępczych mają problemy z usamodzielnieniem się (NIK 2014), a w dodatku są dużo bardziej zagrożeni wykluczeniem społecznym, marginalizacją czy wręcz alienacją. Z badań prowadzonych w Rosji na podstawie publicznych statystyk wynika, że co piąte osierocone dziecko opuszczające rosyjski dom dziecka wchodzi na drogę przestępstwa, co siódme zajmuje się prostytucją, a co dziesiąte popełnia samobójstwo (Pashkina 2003, s. 83).

Wyniki prowadzonych w ostatnich dekadach badań nad opieką oraz wychowaniem dzieci i młodzieży jednoznacznie wskazują na negatywne konsekwencje opieki instytucjonalnej. Ograniczanie liczby miejsc w instytucjach opiekuńczych, a następnie likwidacja tych instytucji stały się zatem jednym z kluczowych celów polityki Unii Europejskiej w ostatnich latach (Ogólnoeuropejskie wytyczne... 2012). Jego osiągnięcie wymaga jednak skoordynowania wielu działań na różnych poziomach, $w$ tym przeprowadzenia badań i analiz szczegółowo opisujących sytuację w poszczególnych krajach. W związku z tym zarówno w dokumentach europejskich, jak i w naukowych pracach badawczych podjęto próbę odpowiedzi na pytanie o skalę zjawiska instytucjonalizacji dzieci w Europie i na świecie. Próby te ujawniły, trudności w oszacowaniu liczby dzieci i młodzieży - zarówno na poziomie globalnym, jak i w poszczególnych krajach - pozostających w instytucjach opieki całkowitej. Wynika to m.in. z tego, że instytucje te są administracyjnie rozproszone i, jak widać na przykładzie Polski, brakuje jednolitego systemu raportowania umożliwiającego całościowy monitoring instytucjonalizacji dzieci i młodzieży. Na problemy wynikające $\mathrm{z}$ różnorodności systemów opieki i monitoringu nakładają się ograniczenia związane z dostępem do danych. To wszystko przekłada się na niewielką liczbą przekrojowych analiz umożliwiających ustalenie, choćby w przybliżeniu, liczby dzieci przebywających w instytucjonalnych formach opieki. Największy szacunek dotyczący dzieci wychowujących się w pieczy instytucjonalnej pochodzi z 2009 roku i wskazuje na liczbę przekraczającą dwa miliony. Kluczowa w tym szacunku wydaje się informacja dotycząca dzieci z Europy Środkowo-Wschodniej oraz ze Wspólnoty Niepodległych Państw, z których pochodzi aż 800 tys. dzieci, czyli ponad jedna trzecia wspomnianych $2 \mathrm{mln}$ dzieci znajdujących się w instytucjonalnej pieczy zastępczej (Šiška, Beadle-Brown 2020). Nieco nowsze oszacowanie, będące wynikiem projektu The Transformative Monitoring for Enhanced Equity

\footnotetext{
${ }^{1}$ System pieczy w rozumieniu Ustawy z dnia 9 czerwca 2011 r. o wspieraniu rodziny i pieczy zastępczej (tekst jedn. Dz.U. z 2020 r. poz. 821).
} 
(TransMonEE), wskazuje, że w różnych formach opieki zastępczej w 22 krajach Europy Środkowo-Wschodniej / WNP i Unii Europejskiej znajduje się 1,4 mln dzieci (TransMonEE 2014). Nie określono w nim jednak liczby dzieci wychowujących się w instytucjach, ponieważ połączono liczbę dzieci znajdujących się pod opieką rodzin zastępczych m.in. z kuratelą czy instytucjonalnymi formami opieki. $\mathrm{W}$ efekcie jednym z większych wyzwań jest pozyskanie danych koniecznych do zaplanowania zmian, gdyż bez informacji na temat liczby dzieci przebywających $\mathrm{w}$ instytucjach niemożliwe jest prowadzenie skutecznej polityki zmierzającej do deinstytucjonalizacji, a jeszcze trudniejsze - oszacowanie środków, jakie na taką politykę należałoby przeznaczyć.

Celem artykułu jest dostarczenie informacji na temat łącznej liczby dzieci i młodzieży znajdujących się w instytucjach opieki całkowitej. Są one w nim rozumiane jako zhierarchizowane instytucje zapewniające całodobową opiekę, w ramach której podopiecznym organizowane są zarówno czas, jak i przestrzeń, a umieszczenie $\mathrm{w}$ nich następuje $\mathrm{w}$ wyniku niemożności sprawowania opieki przez rodzinę pochodzenia (np. w wyniku sieroctwa, czy też na skutek niewydolności opiekuńczo-wychowawczej rodziny pochodzenia). Do szacowania liczby dzieci i młodzieży umieszczonych w instytucjach najczęściej wykorzystuje się dane na temat osób znajdujących się w instytucjonalnych formach pieczy zastępczej2, pomijając podopiecznych innych zakładów ${ }^{3}$, takich jak domy pomocy społecznej, zakłady opiekuńczo-lecznicze czy też młodzieżowe ośrodki wychowawcze, co sprawia, że liczba dzieci przebywających pod opieką instytucji jest zaniżana. W artykule podjęto więc próbę oszacowania rzeczywistej liczby dzieci i młodzieży w wieku 0-24 lat znajdujących się we wszystkich instytucjonalnych formach opieki w Polsce w 2019 r.

\section{Instytucjonalne formy opieki całkowitej nad dziećmi i młodzieżą w Polsce}

Liczba dzieci znajdujących się w polskich instytucjach świadczących opiekę całkowitą waha się, w zależności od przyjętych definicji i kryteriów, między 17 tys. a niemal 30 tys. Tak duża rozbieżność wynika m.in. z rozproszenia administracyjnego instytucji opieki i praktyki sprawozdawczej stawiającej znak równości między instytucjonalizacją dzieci i młodzieży a osobami przebywającymi

\footnotetext{
${ }^{2}$ Instytucje działające na podstawie Ustawy z dnia 9 czerwca 2011 r. o wspieraniu rodziny i pieczy zastępczej (tekst. jedn. Dz.U. z 2020 r. poz. 821).

3 Działających na podstawie następujących ustaw: Ustawy z dnia 12 marca 2004 r. o pomocy społecznej (tekst. jedn. Dz.U. z 2020 r. poz. 1876, 2369), Ustawy z dnia 15 kwietnia 2011 r. o działalności leczniczej (tekst. jedn. Dz.U. z 2020 r. poz. 295, 567, 1493) oraz Ustawy z dnia 14 grudnia 2016 r. - Prawo oświatowe (tekst. jedn. Dz.U. z 2020 r. poz. 910, 1378).
} 
w placówkach opiekuńczo-wychowawczych, regionalnych ośrodkach opiekuńczo-terapeutycznych oraz interwencyjnych ośrodkach preadopcyjnych ${ }^{4}$. Nie są to jednak wszystkie instytucje, które przejmują funkcje rodziny biologicznej. Do takich placówek kwalifikują się m.in. domy pomocy społecznej czy zakłady opiekuńczo-lecznicze, ale dzieci w nich przebywające nie są już w statystykach dotyczących pieczy zastępczej uwzględniane. W efekcie dochodzi do znacznego zaniżenia skali instytucjonalizacji, a to może prowadzić do zbyt optymistycznych wniosków dotyczących postępów w deinstytucjonalizacji oraz do niedoszacowania nakładów finansowych, jakie należy przeznaczyć na przejście z opieki instytucjonalnej na środowiskową. Mimo że w długim okresie opieka oparta o rodzinne formy pieczy zastępczej jest również bardziej korzystna finansowo niż opieka instytucjonalna, to sam proces zmiany będzie wymagał krótkookresowego wzrostu nakładów, ważne jest zatem uwzględnienie podopiecznych zakładów i ośrodków funkcjonujących poza systemem pieczy zastępczej w łącznej liczbie dzieci przebywających w instytucjach.

W celu zidentyfikowania miejsc długoterminowego pobytu dzieci i młodzieży dokonano przeglądu ustaw pod kątem zapisów umożliwiających tworzenie i prowadzenie instytucji opieki całkowitej. W efekcie do oszacowania rzeczywistej skali instytucjonalizacji zakwalifikowano dzieci i młodzież znajdujące się w:

1. instytucjonalnych formach pieczy zastępczej w rozumieniu Ustawy z dnia 9 czerwca $2011 \mathrm{r}$. o wspieraniu rodziny i systemie pieczy zastępczej (tekst jedn. Dz.U. z 2020 r. poz. 821);

2. domach pomocy społecznej działających na podstawie Ustawy z dnia 12 marca 2004 r. o pomocy społecznej (tekst jedn. Dz.U. z 2020 r. poz. 1876,2369 );

3. w zakładach o charakterze leczniczym oferujących całodobową opiekę na podstawie Ustawy z dnia 15 kwietnia 2011 r. o działalności leczniczej (tekst jedn. Dz.U. z 2020 r. poz. 295, 567, 1493) oraz Ustawy z dnia 27 sierpnia 2004 r. o świadczeniach opieki zdrowotnej finansowanych ze środków publicznych (tekst jedn. Dz.U. z 2020 r. poz. 1398, 1492, 1493);

4. ośrodkach wychowawczych i socjalizacyjnych działających na podstawie Ustawy z dnia 14 grudnia 2016 r. - Prawo oświatowe (tekst jedn. Dz.U. z 2020 r. poz. 910,1378$)$.

W ogólnym oszacowaniu nie uwzględniono dzieci i młodzieży znajdujących się w placówkach o charakterze penitencjarnym, a także podopiecznych tych placówek edukacyjnych, które co do zasady nie sprawują całkowitej opieki nad dziećmi.

\footnotetext{
${ }^{4}$ Wszystkie te placówki są tworzone i prowadzone na mocy Ustawy z dnia 9 czerwca $2011 \mathrm{r}$. o wspieraniu rodziny i systemie pieczy zastępczej (tekst jedn. Dz.U. z 2020 r. poz. 821).
} 


\section{Piecza zastępcza}

Dolną granicę skali instytucjonalizacji wyznacza liczba dzieci przebywających w placówkach i ośrodkach funkcjonujących w systemie pieczy zastępczej. Zgodnie z art. 93 Ustawy z dnia 9 czerwca 2011 r. o wspieraniu rodziny i systemie pieczy zastępczej do instytucjonalnych form pieczy zastępczej należą:

1. placówki opiekuńczo-wychowawcze,

2. regionalne placówki opiekuńczo-terapeutyczne,

3. interwencyjne ośrodki preadopcyjne.

Wyróżnia się cztery typy placówek opiekuńczo wychowawczych: socjalizacyjne, interwencyjne, rodzinne i specjalistyczno-terapeutyczne. Ze sprawozdań MRPiPS ${ }^{5}$ wynika, że 31 grudnia 2019 r. w Polsce funkcjonowało łącznie $1139^{6}$ placówek, z czego w:

- 833 placówkach typu socjalizacyjnego przebywało 13361 osób,

- 243 placówkach typu rodzinnego znajdowało się 1537 osób,

- 204 placówkach typu interwencyjnego przebywały 1272 osoby,

- 55 placówkach typu specjalistyczno-terapeutycznego znajdowało się 479 osób.

31 grudnia 2019 r. w Polsce funkcjonowało również 10 regionalnych placówek opiekuńczo-terapeutycznych ${ }^{7}$, w których przebywało 309 podopiecznych, oraz trzy interwencyjne ośrodki preadopcyjne, pod opieką których znajdowało się 34 dzieci. Łącznie na koniec grudnia 2019 r. we wszystkich instytucjach pieczy zastępczej przebywało 16992 dzieci i młodzieży w wieku od 0 do 24 lat, z czego zdecydowana większość znajdowała się w placówkach opiekuńczo-wychowawczych (98\%). Należy zauważyć, że zgodnie z wprowadzanymi sukcesywnie zmianami umieszczanie dzieci w placówkach opiekuńczo-wychowawczych zostało znacznie ograniczone, gdyż przepisy (Ustawy z dnia 9 czerwca

\footnotetext{
${ }^{5}$ Dane ze sprawozdań rzeczowo-finansowych z wykonywania zadań z zakresu wspierania rodziny i systemu pieczy zastępczej. Sprawozdania przygotowywane są zgodnie ze wzorami określonymi w Rozporządzeniu Ministra Rodziny Pracy i Polityki Społecznej w sprawie sprawozdań rzeczowo-finansowych z wykonywania zadań z zakresu wspierania rodziny i systemu pieczy zastępczej na podstawie art. 187 ust. 6 Ustawy z dnia 9 czerwca 2011 r. o wspieraniu rodziny i systemie pieczy zastępczej (tekst jedn. Dz.U. z 2020 r. poz. 821 z późn. zm.).

${ }^{6}$ Suma poszczególnych typów placówek jest większa niż łączna liczba placówek opiekuńczo-wychowawczych, gdyż placówki opiekuńczo-wychowawcze, zgodnie z art. 101 pkt 3 Ustawy o WRiSPZ, mogły łączyć zadania placówek różnego typu (z wyłączeniem typu rodzinnego).

${ }^{7}$ Regionalne placówki opiekuńczo-terapeutyczne przeznaczone są dla dzieci, wymagających szczególnej opieki, które ze względu na stan zdrowia wymagają specjalistycznej opieki i rehabilitacji oraz nie mogą zostać umieszczone w rodzinnej pieczy zastępczej lub placówce opiekuńczo-wychowawczej.
} 
$2011 \mathrm{r}$ o wspieraniu rodziny i systemie pieczy zastępczej, art. 95.1) nie pozwalają, z pewnymi wyjątkami ${ }^{8}$, na umieszczenie w nich dzieci poniżej 10 roku życia. W placówce opiekuńczo-wychowawczej nie można też umieścić w tym samym czasie więcej niż 14 dzieci i młodzieży9.

Przytoczone dane są najczęściej przywoływane w kontekście szacowania skali instytucjonalizacji dzieci i młodzieży w Polsce. Wymagają one jednak uzupełnienia, gdyż nie można ignorować istnienia innych form długoterminowej opieki nad dziećmi, których Ustawa z dnia 9 czerwca 2011 r. o wspieraniu rodziny i pieczy zastępczej nie obejmuje swym zakresem.

\section{Domy pomocy społecznej}

W Polsce dzieci i młodzież mogą również zostać umieszczone w domach pomocy społecznej (DPS). Art 56 Ustawy z dnia 12 marca 2004 r. o pomocy społecznej umożliwia prowadzenie DPS dla dzieci i młodzieży niepełnosprawnej intelektualnie, a także łączenie, na podstawie art. 56a, w jednym budynku różnego typu domów, w tym DPS dla osób dorosłych niepełnosprawnych intelektualnie oraz DPS dla dzieci i młodzieży niepełnosprawnej intelektualnie. Łącznie na koniec grudnia 2019 r. rzeczywista liczba funkcjonujących w Polsce DPS dla dzieci i młodzieży niepełnosprawnych intelektualnie wynosiła 38 , a dla osób dorosłych niepełnosprawnych intelektualnie oraz dzieci i młodzieży niepełnosprawnych intelektualnie $-69^{10}$. Dane sprawozdawcze nie zawierają szczegółowych informacji na temat roku urodzenia mieszkańców poszczególnych typów DPS, nie można zatem na ich podstawie oszacować rzeczywistej liczby dzieci i młodzieży przebywających w poszczególnych typach domów. Z analizy zawartych w sprawozdaniu danych wynika jednak, że miejsc i mieszkańców DPS dla dzieci i młodzieży niepełnosprawnej intelektualnie jest więcej niż przebywających $\mathrm{w}$ nich osób ${ }^{11} \mathrm{w}$ wieku 0-24 lat. Wynika to z tego, że w domu dla dzieci i młodzieży niepełnosprawnej

\footnotetext{
${ }^{8}$ Umieszczenie dziecka poniżej 10 roku życia w placówce-opiekuńczo wychowawczej jest możliwe na podstawie art. 95 ust. $2 \mathrm{w}$ przypadku, gdy umieszona jest w niej matka lub ojciec tego dziecka lub w innych wyjątkowych przypadkach, szczególnie gdy przemawia za tym stan zdrowia dziecka lub dotyczy to rodzeństwa.

${ }^{9} \mathrm{Z}$ wyjątkiem placówki opiekuńczo-wychowawczej typu rodzinnego, w której może znajdować się nie więcej niż ośmioro dzieci i młodzieży, a w przypadku rodzeństwa - nie więcej niż 10 osób. Ustawa wprowadziła również okres przejściowy dla placówek funkcjonujących przed 1 stycznia 2012 r., dopuszczając umieszczenie w nich maksymalnie 30 osób, jednak dojście do 14-osobowego standardu musi nastąpić do 2 stycznia $2021 \mathrm{r}$.

${ }^{10}$ Wszystkie przytoczone dane pochodzą ze Sprawozdań o placówkach zapewniajacych całodobowa opiekę i wsparcie (MRPiPS-05).

${ }^{11} 31$ grudnia 2019 r. w 38 rzeczywiście funkcjonujących DPS dla dzieci i młodzieży niepełnosprawnych intelektualnie mieszkało 2561 osób.
} 
intelektualnie mogą przebywać osoby, które ukończyły 30 rok życia, pod warunkiem że mają one małą zdolność adaptacji do nowego otoczenia i przebywają w tym domu ponad pięć lat (Rozporządzenie Ministra Pracy i Polityki Społecznej z dnia 23 sierpnia 2012 r. w sprawie domów pomocy społecznej). Na podstawie typu domu nie można zatem wnioskować o przynależności jego mieszkańców do określonej grupy wiekowej. Ostatecznie liczbę dzieci i młodzieży przebywających w DPS ustalono na podstawie roku urodzenia mieszkańców bez względu na typ domu, w jakim przebywali. 31 grudnia 2019 r. liczba dzieci i młodzieży znajdujących się w DPS wynosiła 2168 osób w wieku 0-24 lat (w tym 852 dzieci w wieku 0-18 lat). W 2019 r. odnotowano nieznaczny spadek (o 5\%) liczby dzieci i młodzieży przebywających w DPS w porównaniu z rokiem 2018.

\section{Zakłady opiekuńczo-lecznicze, zakłady pielęgnacyjno-opiekuńcze, hospicja stacjonarne i oddziały medycyny paliatywnej}

Kolejną grupą, którą należy wziąć pod uwagę, szacując liczbę dzieci znajdujących się w instytucjach opieki całkowitej, są dzieci przebywające w zakładach realizujących świadczenia na podstawie Ustawy z dnia 15 kwietnia 2011 r. o działalności leczniczej oraz Ustawy z dnia 27 sierpnia 2004 r. o świadczeniach opieki zdrowotnej finansowanych ze środków publicznych, oferujących całodobową opiekę zarówno dla dorosłych jak i dla dzieci i młodzieży. Chodzi przede wszystkim o zakłady opiekuńczo-lecznicze oraz zakłady pielęgnacyjno-opiekuńcze, a także hospicja stacjonarne i oddziały medycyny paliatywnej. Zakłady opiekuńczo-lecznicze (ZOL) oraz zakłady pielęgnacyjno-opiekuńcze (ZPO) zapewniają długoterminową opiekę medyczną oraz pielęgnację pacjentom niewymagającym hospitalizacji. Są to osoby w pełni zdiagnozowane, u których zakończono proces leczenia, jednak ich stan zdrowia nie pozwala na samodzielne funkcjonowanie. Zakłady te udzielają świadczeń zdrowotnych, które obejmują pielęgnację, opiekę i rehabilitację. W tego typu jednostkach prowadzona jest również edukacja zdrowotna dla pacjentów i członków ich rodzin, organizowane są w nich też zajęcia z zakresu samoopieki i samopielęgnacji przygotowujące do życia w warunkach domowych (Ustawa z dnia 15 kwietnia 2011 r. o działalności leczniczej, art. 9.1). Hospicja stacjonarne i oddziały medycyny paliatywnej (OHP) zapewniają wszechstronną całodobową opiekę zdrowotną, psychologiczną i społeczną pacjentom znajdującym się w stanie terminalnym, pomagają one także rodzinom tych pacjentów (Ustawa z dnia 27 sierpnia 2004 r. o świadczeniach opieki zdrowotnej finansowanych ze środków publicznych). Opieka ta jest ukierunkowana przede wszystkim na poprawę jakości życia pacjentów, w tym na zapobieganie 
bólowi i innym objawom somatycznym, a także na łagodzenie cierpień psychicznych, duchowych i socjalnych (Rozporządzenie Ministra Zdrowia z dnia 29 października 2013 r. w sprawie świadczeń gwarantowanych z zakresu opieki paliatywnej i hospicyjnej, § 3 ust. 1).

$Z$ danych Narodowego Funduszu Zdrowia ${ }^{12}$ wynika, że we wszystkich wspomnianych typach placówek (ZOL, ZOP i OHP) w 2019 r. przebywało łącznie 837 osób w wieku 0-24 lat ${ }^{13}$. Zdecydowana większość, tj. 634 osoby, przebywała w zakładach opiekuńczo-leczniczych i zakładach pielęgnacyjno-opiekuńczych.

\section{Młodzieżowe ośrodki wychowawcze i młodzieżowe ośrodki socjoterapii}

Do instytucjonalnych form opieki całkowitej zakwalifikowano również placówki oferujące instytucjonalną całodobową opiekę nad dziećmi i młodzieżą na podstawie Ustawy z dnia 14 grudnia 2016 r. - Prawo oświatowe, tj. młodzieżowe ośrodki wychowawcze oraz młodzieżowe ośrodki socjoterapii. Młodzieżowy ośrodek wychowawczy (MOW) to placówka przeznaczona dla dzieci i młodzieży niedostosowanej społecznie, wymagających specjalnej organizacji nauki, metod pracy, wychowania, pomocy psychologiczno-pedagogicznej i resocjalizacji. W MOW przebywają dzieci i młodzież niedostosowane społecznie, w tym dzieci i młodzież niedostosowane społecznie z niepełnosprawnością intelektualną w stopniu lekkim, w przypadku których sąd rodzinny zastosował środek wychowawczy w postaci umieszczenia w ośrodku (Rozporządzenie Ministra Edukacji Narodowej z dnia 13 listopada 2015 r. w sprawie rodzajów i szczegółowych zasad działania placówek publicznych...). Co do zasady mogą w nich przebywać dzieci do 18 roku życia (wyjątek stanowią sytuacje, w których wychowanek wnioskuje o dokończenie nauki w szkole w MOW). Młodzieżowy ośrodek socjoterapii (MOS) to placówka dla dzieci i młodzieży, które z powodu zaburzeń rozwojowych, trudności w uczeniu się i zaburzeń w funkcjonowaniu społecznym są zagrożone niedostosowaniem społecznym i wymagają specjalnej organizacji nauki, metod pracy, wychowania oraz pomocy psychologiczno-pedagogicznej i socjoterapii (Rozporządzenie Ministra Edukacji Narodowej z dnia 13 listopada 2015 r. w sprawie rodzajów i szczegółowych zasad działania placówek publicznych...). Mogą w nich przebywać dzieci i młodzież do ukończenia 24 roku życia.

\footnotetext{
${ }^{12}$ Dane pozyskane z informacji NFZ w odpowiedzi na wniosek o udostępnienie informacji na temat liczby dzieci przebywających w zakładach opiekuńczo-leczniczych, zakładach pielęgnacyjno-opiekuńczych, na oddziałach medycyny paliatywnej oraz w hospicjach stacjonarnych.

${ }^{13} \mathrm{~W}$ grupie tej znalazło się $276 \mathrm{dzieci}$ (w wieku 0-18 lat).
} 
Dane dotyczące liczby osób przebywających w tego typu ośrodkach w $2019 \mathrm{r}$. nie były niestety dostępne, gdyż z powodu epidemii SARS-CoV-2 wydłużono terminy składania sprawozdań za 2019 r. z działalności niektórych jednostek. Ostatnie dostępne dane GUS dotyczyły 2018 r. - zgodnie z nimi w MOW i MOS przebywało łącznie 9365 dzieci i młodzieży. Korzystając z danych dotyczących poprzednich okresów, oszacowano liczbę dzieci i młodzieży przebywających w wymienionych ośrodkach.

Wykres 1. Oszacowanie liczby dzieci i młodzieży przebywających w MOW i MOS na podstawie funkcji trendu liniowego

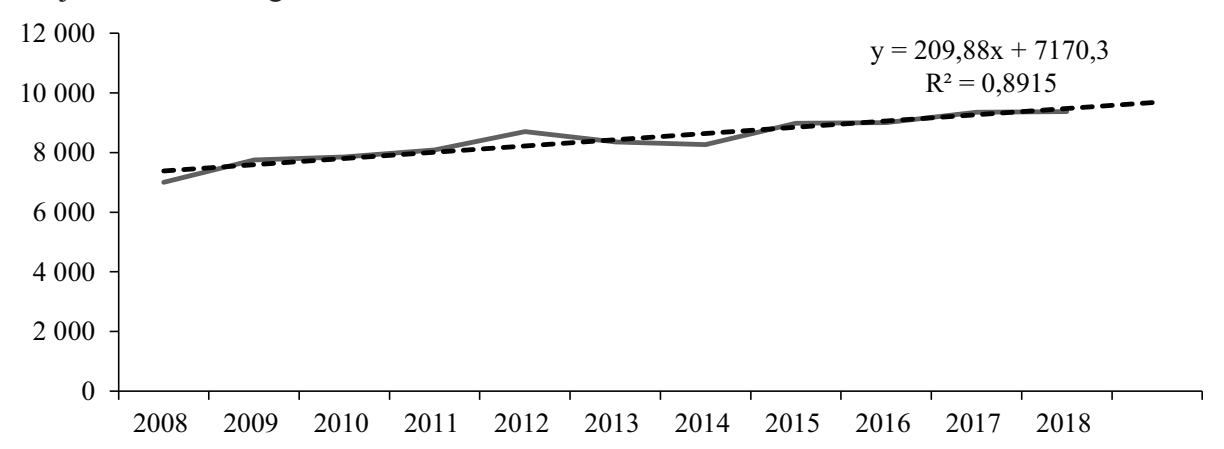

Źródło: obliczenia własne na podstawie danych GUS.

Liczbę dzieci przebywających w MOW i MOS w 2019 r. oszacowano na podstawie interpolacji linii trendu wyznaczonej dla obserwacji z okresu historycznego. W pierwszej kolejności oszacowano parametry liniowej funkcji trendu dla danych rzeczywistych pochodzących z lat 2008-2018. Ze względu na bardzo dobre dopasowanie funkcji trendu do danych empirycznych $\left(\mathrm{R}^{2}=0,89\right)$ uzyskane na podstawie modelu oszacowania parametrów wykorzystano do wyznaczenia wartości teoretycznej zmiennej objaśnianej (tj. liczby dzieci) w kolejnym roku następującym po okresie historycznym, tj. w 2019 r. Z oszacowania wynika, że w 2019 r. w młodzieżowych ośrodkach wychowawczych oraz młodzieżowych ośrodkach socjoterapii przebywało łącznie 9689 osób.

\section{Łączna liczba dzieci i młodzieży przebywająca w instytucjonalnych formach opieki w Polsce a wyzwania procesu deinstytucjonalizacji}

Uzyskane dane pozwalają jedynie na podanie szacunkowej łącznej liczby dzieci i młodzieży znajdujących się w instytucjonalnych formach opieki całkowitej w Polsce w 2019 r. Uwzględniając liczbę dzieci przebywających w placówkach 
systemu pieczy zastępczej (placówkach opiekuńczo-wychowawczych, regionalnych placówkach opiekuńczo-terapeutycznych oraz interwencyjnych ośrodkach preadopcyjnych), instytucjonalnych formach długoterminowej stacjonarnej opieki o charakterze opiekuńczo-leczniczym (zakładach opiekuńczo-leczniczych, zakładach pielęgnacyjno-opiekuńczych, a także hospicjach i oddziałach medycyny paliatywnej) oraz instytucjonalnych formach szkolno-wychowawczych (młodzieżowych ośrodkach wychowawczych i młodzieżowych ośrodkach socjoterapii), można stwierdzić, że w 2019 r. przebywało w nich w przybliżeniu 29686 osób w wieku 0-24 lat.

Wykres 2. Liczba dzieci i młodzieży w wieku 0-24 lat przebywających w placówkach opieki całkowitej w Polsce w 2019 r. ${ }^{14}$

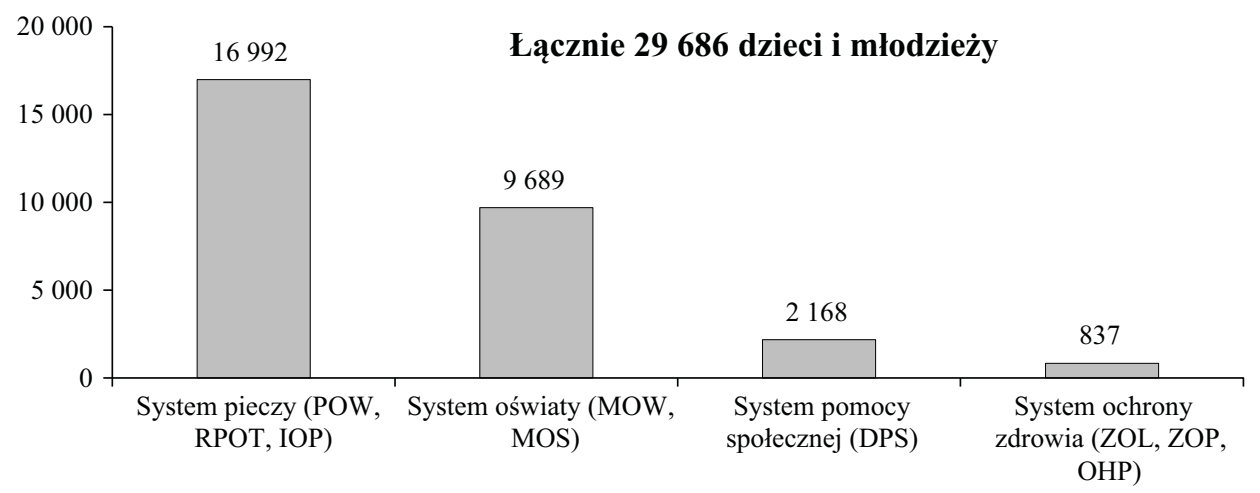

Źródło: obliczenia własne na podstawie danych sprawozdawczych MRPiPS, NFZ oraz GUS, BDL.

Proces deinstytucjonalizacji, który będzie wymagać przekształcenia blisko 30 tys. miejsc $\mathrm{w}$ instytucjach $\mathrm{w}$ rodzinne formy opieki oraz usługi świadczone w środowisku lokalnym, jest dużym wyzwaniem legislacyjnym, organizacyjnym i społecznym.

Zgodnie z Ogólnoeuropejskimi wytycznymi... kraje członkowskie, w tym Polska, zobowiązane są do opracowania strategii deinstytucjonalizacji określającej ogólne ramy reformy pomocy społecznej oraz innych systemów, a także docelową datę zamknięcia instytucji (Ogólnoeuropejskie wytyczne... 2012, s. 71). Jednocześnie należy wdrożyć systemowe zmiany we wsparciu rodziny, zmierzające do intensyfikacji działań o charakterze profilaktycznym, ukierunkowane na ochronę praw dzieci i poprawę kompetencji rodzin. Zakłady nie mogą zostać zamknięte przed wdrożeniem odpowiednich rozwiązań i usług, a ich potencjał i zasoby powinny zostać wykorzystane do realizacji zadań z zakresu wsparcia rodziny w środowisku lokalnym.

${ }^{14}$ Dane za 2019 rok dla MOW i MOS na podstawie szacunku wykonanego na podstawie danych GUS za okres od 2008 r. do 2018 r. 
Powstać też muszą miejsca w rodzinnych formach pieczy zastępczej, co wymaga m.in. przezwyciężenia obserwowanego od lat kryzysu rozwoju rodzicielstwa zastępczego w Polsce (Basiaga 2015; Mickiewicz-Stopa 2017; Chomczyński, Pyżalski, Kacprzak 2019). Już od dawna autorzy opracowań naukowych zwracają uwagę m.in. na malejącą liczbę kandydatów na zawodowych rodziców zastępczych oraz stosunkowo dużą liczbę rodzin rezygnujących z pełnienia tej funkcji. Na sytuację tę ma wpływ wiele czynników, jednak jednymi z głównych są według badaczy wadliwie działający system wsparcia oraz warunki finansowe. Zawodowe rodziny zastępcze, zgodnie z Ustawą z 9 czerwca 2011 r. o wspieraniu rodziny i systemie pieczy zastępczej, uprawnione są do otrzymywania wynagrodzenia w wysokości nie niższej niż 2000 zł, przy czym ustawa nie precyzuje, czy jest to kwota netto, czy brutto (Ustawa z dnia 9 czerwca 2011 r. o wspieraniu rodziny i systemie pieczy zastępczej). Za pracę (na podstawie umowy-zlecenia) wynagrodzenie otrzymuje tylko jeden rodzic. Przyjmując, że wymieniona w ustawie kwota jest kwotą brutto, a pracę rodzic wykonuje przez 16 a nie 24 godziny dziennie oraz że miesiąc liczy średnio 30 dni, można wyliczyć, że otrzymuje on 4,17 zł za godzinę. Dla porównania - minimalna płaca krajowa w 2019 r. w Polsce wynosiła 2250 zł brutto, co oznacza, że osoba zatrudniona na cały etat na podstawie umowy o pracę za tę najniższą stawkę, otrzymywała 14,70 zł za godzinę. W przypadku, gdy rodzic zastępczy otrzymuje najniższą przewidzianą ustawą kwotę wynagrodzenia, świadczy on tę wymagającą i odpowiedzialną pracę za pensję niższą niż minimalna płaca krajowa. Udzielenie odpowiedzi na pytanie o to, czy wzrost tej kwoty przyczyniłby się do rozwoju rodzinnej pieczy zastępczej w Polsce, powinno stać się celem dalszych badań. Patrząc jednak z czysto ekonomicznego punktu widzenia, rodzinne formy opieki nad dziećmi są zdecydowanie mniej kosztowne niż instytucjonalne. Dla porównania - w 2019 r. średni miesięczny koszt utrzymania dziecka w placówce opiekuńczo-wychowawczej wynosił 5888 zł, a w rodzinie zastępczej zawodowej i w rodzinnym domu dziecka - 2284 zł, czyli ok. 39\% średniego miesięcznego kosztu utrzymania dziecka w placówce opiekuńczo-wychowawczej ${ }^{15}$. Zwiększenie przyznawanej obecnie rodzicom zastępczym pensji ${ }^{16}$ do średniej krajowej z 2019 r., tj. do 4918 zł, sprawiłoby, że średni miesięczny koszt utrzymania jednego dziecka w rodzinie zastępczej wzrósłby do 3060 zł, co stanowiłoby $52 \%$ obecnej kwoty przeznaczanej miesięcznie na dziecko w placówce opiekuńczo-wychowawczej.

\footnotetext{
${ }^{15}$ Obliczenia własne na podstawie danych systemu CeSAR zawierającego informacje ze sprawozdań rzeczowo-finansowych z wykonywania zadań z zakresu wspierania rodziny i systemu pieczy zastępczej.

${ }^{16}$ Obliczenia własne na podstawie średniej wysokości pensji rodziców zastępczych w 2019 r. oraz sumy wszystkich wydatków ponoszonych na pieczę zastępczą, które zwiększono o 2120,43 zł, tj. o różnicę między średnią wysokością pensji w 2019 r. (dane na podstawie systemu CeSAR) a średnią pensją krajową za 2019 r. (według GUS).
} 
Mimo że w okresie przejściowym wydatki najprawdopodobniej wzrosną - gdyż finansowania wymagać będą zarówno nowa sieć usług, jak i niewygaszone miejsca opieki instytucjonalnej - to po pewnym czasie sytuacja się ustabilizuje, gdyż zgodnie z założeniami właściwie poprowadzona deinstytucjonalizacja, tj. dobrze skoordynowana we wszystkich sektorach, może przynieść znaczne oszczędności (Tomalak i in. 2011, s. 28). Ponadto zgodnie z założeniami procesu deinstytucjonalizacji, wraz $\mathrm{z}$ rozwojem środowiskowych usług wsparcia rodziny przeżywającej trudności opiekuńczo-wychowawcze zapotrzebowanie na miejsca w pieczy zastępczej powinno się zmniejszać. Określenie rzeczywistej skali nakładów i oszczędności wymaga dalszych pogłębionych badań opierających się na konkretnych założeniach strategicznych, jednak warto zauważyć, że ewentualny zysk ekonomiczny to niewiele znaczący dodatek do zysku społecznego i szansy, jaką dzięki deinstytucjonalizacji otrzyma każda wymagająca wsparcia jednostka.

\section{Podsumowanie}

Przeprowadzone badania ujawniły znaczne niedoszacowanie liczby dzieci i młodzieży przebywających w instytucjach opieki całkowitej w Polsce. W 2019 r. ich liczba wyniosła łącznie niemal 30 tys., podczas gdy według najczęściej przytaczanych podsumowań (dotyczących tylko systemu pieczy zastępczej) niespełna 17 tys. Skomplikowany proces pozyskania danych o wychowankach poszczególnych instytucji opieki całkowitej świadczy o braku koordynacji międzyresortowych działań mających na celu wspieranie dzieci i młodzieży, a także o niewystarczającym przygotowaniu do przeprowadzenia deinstytucjonalizacji w Polsce. Brakuje wspólnego systemu monitorowania liczby dzieci i młodzieży pozbawionych opieki rodziny biologicznej, dane dotyczące poszczególnych instytucji są rozproszone, a ich udostępnianie i publikowanie odbywa się na odrębnych, właściwych danemu resortowi zasadach, w związku z czym żadna z instytucji zajmujących się problematyką dzieci i młodzieży nie posiada pełnej wiedzy na temat skali instytucjonalizacji osób w wieku 0-24 lat. Budzi to poważne obawy o powodzenie deinstytucjonalizacji w omawianym obszarze, ponieważ jeśli zostanie ona zaplanowana na podstawie zaniżonych danych, to w efekcie m.in. niedoszacowania środków potrzebnych na jej przeprowadzanie, wiele działań nie zostanie $\mathrm{z}$ sukcesem zrealizowanych lub też ich efekty będą inne niż zakładano.

Praktyka nieuwzględniania w sprawozdaniach i statystykach dzieci i młodzieży znajdujących się poza systemem pieczy zastępczej może również przyczynić się do wzrostu umieszczeń dzieci w „niewidocznych” dla systemu zakładach. W 2019 r. w placówkach opiekuńczo-wychowawczych znajdowało się łącznie 
1355 dzieci poniżej 7 roku życia, mimo że przepisy Ustawy z dnia 9 czerwca 2011 r. o wspieraniu rodziny i systemie pieczy zastępczej nie pozwalały (z pewnymi wyjątkami) na umieszczenie w nich dzieci w tym wieku. Można zatem przypuszczać, że w związku np. ze źle zaplanowaną liczbą potrzebnych miejsc w rodzinnych formach pieczy zastępczej, te najmłodsze dzieci i tak zostaną niezgodnie z prawem przyjęte do placówek opiekuńczo-wychowawczych lub też zostaną umieszczone w zakładach funkcjonujących poza systemem pieczy zastępczej, np. w domach pomocy społecznej, w których nie obowiązują ograniczenia wiekowe. Przenoszenie dzieci między systemami może stać się powszechną praktyką, dlatego określenie rzeczywistej liczby dzieci i młodzieży znajdujących się w instytucjach opieki całkowitej oraz obowiązek bieżącego monitorowania skali instytucjonalizacji wydają się warunkiem koniecznym skutecznej deinstytucjonalizacji w obszarze wspierania rodziny i pieczy zastępczej.

\section{Bibliografia}

Basiaga J. (2015), Czynniki utrudniajace funkcjonowanie zawodowych rodzin zastępczych, „Polityka Społeczna”, 1.

Bos K. et al. (2011), Psychiatric Outcomes in Young Children with a History of Institutionalization, „Harvard Review of Psychiatry”, 19: 15-24.

Browne K. (2009), The Risk of Harm to Young Children in Institutional Care, Save the Children, London.

Centralna Aplikacja Statystyczna, Ocena zasobów pomocy społecznej, http://cas. mpips.gov.pl/CAS/Pliki (data dostępu: 7.08.2020).

Chomczyński P., Pyżalski J., Kacprzak A. (2019), Zawodowe rodziny zastępcze i rodzinne domy dziecka w województwie tódzkim, Regionalne Centrum Polityki Społecznej, Łódź.

Główny Urząd Statystyczny, Bank Danych Lokalnych, https://bdl.stat.gov.pl/ BDL/start (data dostępu: 7.08.2020).

Główny Urząd Statystyczny (2017), Zdrowie i ochrona zdrowia w 2016, https:// stat.gov.pl/files/gfx/portalinformacyjny/pl/defaultaktualnosci/5513/1/7/1/ zdrowie_i_ochrona_zdrowia_w_2016.pdf(data dostępu: 7.08.2020).

Golczyńska-Grondas A. (2015), Underprivileged Children in the Social Space of Impunity: The Example of the Children's Residential Care System in the Polish People's Republic, „Przegląd Socjologiczny”, LXIV(1): 103-120.

Hodges J., Tizard B. (1989), IQ and Behavioural Adjustment of Ex-Institutional Adolescents, ,Journal of Child Psychology and Psychiatry, and Allied Disciplines", 30: 53-75.

Holm H.J., Kristofersen L.B., Myrvold T.M. (red.) (2003), Orphans in Russia, Norwegian Institute for Urban and Regional Research, Oslo. 
Jackson L. et al. (2010), Exploring Spirituality Among Youth in Foster Care: Findings from the Casey Field Office Mental Health Study, „Child and Family Social Work", 15: 107-117.

Luberadzka-Gruca J. (2019), Deinstytucjonalizacja systemu pieczy zastępczej-analiza, dobre praktyki, https://wuplodz.praca.gov.pl/documents/1135458/4472799/ Deinstytucjonalizacja\%20systemu\%20pieczy\%20zast\%C4\%99pczej\%20 \%28analiza\%2C\%20dobre\%20praktyki\%29.pdf/5f07a4e1-1ece-4ec7-aef7-b8d53f9bd58c?t=1523353951716 (data dostępu: 7.08.2020).

Mickiewicz-Stopa K. (2017), Trudności zawodowych rodzin zastępczych w perspektywie opiekunów zastępczych, koordynatorów rodzinnej pieczy zastępczej oraz asystentów rodziny, „Problemy Opiekuńczo-Wychowawcze”, 5.

Ministerstwo Rodziny i Polityki Społecznej, System CeSAR, Sprawozdania rzeczowo-finansowe z wykonywania zadań z zakresu wspierania rodziny i systemu pieczy zastępczej, II kwartał.

Ministerstwo Rodziny i Polityki Społecznej, System CeSAR, Sprawozdania $z$ udzielonych świadczeń pomocy społecznej-pieniężnych, w naturze i ustugach (MRPiPS-03).

Ministerstwo Rodziny i Polityki Społecznej, System CeSAR, Sprawozdanie o placówkach zapewniajacych całodobowa opiekę i wsparcie (MRPiPS-05).

Nelson C., Koga S. (2004), Effects of institutionalisation on brain and behavioural development in young children: Findings from The Bucharest Early Intervention Project (referat przedstawiony na międzynarodowej konferencji poświęconej ustaleniu liczby i cech zagrożonych dzieci w wieku do lat trzech przebywających w zakładach na terenie Europy), EU Daphne Programme, WHO Regional Office for Europe, København.

NIK (2012), Informacja o wynikach kontroli. Funkcjonowanie placówek opiekuńczo-wychowawczych oraz ich współdziałanie z innymi instytucjami na rzecz powrotu dzieci do wychowania $w$ rodzinie, Warszawa.

NIK (2014), Informacja o wynikach kontroli. Pomoc w usamodzielnianiu się wychowanków pieczy zastępczej, Warszawa.

Ogólnoeuropejskie wytyczne dotyczace przejścia od opieki instytucjonalnej do opieki świadczonej na poziomie lokalnych spoteczności (2012), Europejska Grupa Ekspertów ds. Przejścia od Opieki Instytucjonalnej do Opieki Świadczonej na Poziomie Lokalnych Społeczności, https://www.funduszeeuropejskie.gov.pl/media/17881/12.pdf (data dostępu: 3.08.2020).

Petrowski N., Cappa C., Gross P. (2017), Estimating the Number of Children in Formal Alternative Care: Challenges and Results, „Child Abuse \& Neglect”, 70: 388-398.

Rozporządzenie Ministra Edukacji Narodowej z dnia 13 listopada 2015 r. w sprawie rodzajów i szczegółowych zasad działania placówek publicznych, warunków pobytu dzieci i młodzieży w tych placówkach oraz wysokości 
i zasad odpłatności wnoszonej przez rodziców za pobyt ich dzieci w tych placówkach (Dz.U. z 2015 r., poz. 1872).

Rozporządzenia Ministra Pracy i Polityki Społecznej z dnia 23 sierpnia 2012 r. w sprawie domów pomocy społecznej (tekst jedn. Dz.U. z 2018 r., poz. 734). Rozporządzenie Ministra Zdrowia z dnia 29 października 2013 r. w sprawie świadczeń gwarantowanych z zakresu opieki paliatywnej i hospicyjnej (tekst jedn. Dz.U. z 2018 r., poz. 742).

Rutter M., O'Connor T.G., The English and Romanian Adoptees (ERA) Study Team (2004), Are There Biological Programming Effects for Psychological Development?, Findings From a Study of Romanian Adoptees, „Developmental Psychology", 40(1): 81-94.

Schmid M. et al. (2008), Prevalence of Mental Disorders among Adolescents in German Youth Welfare Institutions, „Child and Adolescent Psychiatry and Mental Health", 2(2).

Szmajda R., Gmitrowicz A. (2018), Selected Mental Health Problems in Institutionally Reared Children, „Psychiatria i Psychologia Kliniczna”, 18: 354-363.

Šiška J., Beadle-Brown, J. (2020), Transition from Institutional Care to Community-Based Services in 27 EU Member States: Final Report, Research Report for the European Expert Group on Transition from Institutional to Community-based Care.

Tizard B., Rees J. (1975), The Effect of Early Institutional Rearing on the Behavior Problems and Affectional Relationships of Four-Year-Old Children, „Journal of Child Psychology and Psychiatry, and Allied Disciplines”, 16: $61-73$.

Tomalak D., Halloran J., Barnett S. (2011), Tworzenie modelu pomocy środowiskowej. Dlaczego zmiana jest potrzebna i jak ja przeprowadzać, European Social Network, Brighton.

UNICEF (2011), Early Childhood Development, What Parliamentarians Need to Know and Do, http://www.unicef.by/uploads/models/2017/02/unicef_ecd what_parliaments_v41.pdf (data dostępu: 7.08.2020).

UNICEF (2014), Transformative Monitoring for Enhanced Equity. Key Features, http://transmonee.org/wp-content/uploads/2016/07/TM_2014_brochure_v1.pdf (data dostępu: 7.08.2020).

Ustawa z dnia 12 marca 2004 r. o pomocy społecznej (tekst jedn. Dz.U. z 2020 r., poz. 1876, 2369).

Ustawa z dnia 27 sierpnia 2004 r. o świadczeniach opieki zdrowotnej finansowanych ze środków publicznych (tekst jedn. Dz.U. z 2020 r., poz. 1398, 1492, 1493).

Ustawa z dnia 15 kwietnia 2011 r. o działalności leczniczej (tekst jedn. Dz.U. z 2020 r., poz. 295, 567, 1493). 
Ustawa z dnia 9 czerwca 2011 r. o wspieraniu rodziny i systemie pieczy zastępczej (tekst jedn. Dz.U. z 2020 r., poz. 821).

Ustawa z dnia 14 grudnia 2016 r. - Prawo oświatowe (tekst jedn. Dz.U. z 2020 r., poz. 910, 1378).

\section{Summary}

The actual number of children and young people in institutional care in Poland and the challenges of the deinstitutionalization process

This article was written in response to the need for data on the number of children and young people in residential care institutions in Poland. This is crutial for estimating the scale of necessary actions to be taken in order to transition from institutional foster care to family care provisions (deinstitutionalization). The main problem associated with analyzing the conditions of the deinstitutionalization process and, consequently, its planning in the area of supporting children and young people in Poland, is that children and youngsters located outside the foster care system are entirely ignored, both in professional discourse and in statistics. The author presents the consequences of such an approach, analyzing the number of people aged 0 to 24 placed in residential care institutions in social welfare, education, and public health systems. The analysis indicates a significant underestimation of the scale of institutionalization of children and youth in Poland, which, depending on the adopted criteria for qualifying institutions, ranges from $20 \%$ to $35 \%$ of all people in 2019 placed outside their families of origin. The lower number of this estimation is determined by the share of children and youth placed in institutions that operate within the foster care system (almost 17,000 people), while the upper limit/number is the total number of people aged 0-24 in all institutional care provision, including, residential care homes or care and treatment institutions, among others (almost 30,000 people).

Keywords: deinstitutionalization, alternative care, residential care institution/ institutional foster care, social policy, social economy. 